\title{
Identification of the predictors of preference for alfalfa hay by equines
}

\author{
Identificação dos preditores de preferência pelo feno de alfafa por equínos
}

\author{
OLIVEIRA, Kátia de ${ }^{1 *} ;$ SÁ, Janaína Carolina de ${ }^{1}$; COSTA, Ciniro ${ }^{2}$; MEIRELLES, \\ Paulo Roberto de Lima ${ }^{2}$; FACHIOLLI, Daniele Floriano ${ }^{2}$; PEREIRA, Amanda \\ Mantovani ${ }^{1}$
}

\begin{abstract}
${ }^{1}$ Universidade Estadual Paulista, Faculdade de Ciências Agrárias e Tecnológicas, Dracena,São Paulo, Brasil. ${ }^{2}$ Universidade Estadual Paulista, Faculdade de Medicina Veterinária e Zootecnia, Botucatu, São Paulo, Brasil. *Endereço para correspondência: katia@dracena.unesp.br
\end{abstract}

\section{SUMMARY}

The purpose of this study was to identify predictors of preference for alfalfa hay by equines. A total of 15 quarter horses, at average age and body weight of 10 years and $500 \mathrm{~kg}$ were used, respectively. It was conducted an evaluation to identify the preference for alfalfa hay by horses by short-period tests of $10 \mathrm{~min}$. This evaluation was conducted in pairs for each test hay (1-30), available on the market, against each standard (A, B, C), until the completion of all resulting combinations. Alfalfa hays classified as $\mathrm{A}, \mathrm{B}$ and $\mathrm{C}$, contained on average $22.88,17.78$ and $13.16 \%$ of crude protein, respectively. The evaluated variables were constituted by ethological, morphological, microbiological, bromatological and biological analysis. The horses showed a preference for the type A of alfalfa hay, followed by type B and C. The preference for alfalfa hay type A can be predicted by the equation: Pref. $\mathrm{A}=-98.19+1.61$ (acid detergent fiber) +1.53 (in vitro dry matter digestibility) +18.54 (stem thickness) -0.03 (acid detergent fiber $\mathrm{x}$ in vitro dry matter digestibility) - 0.02(acid detergent fiber $\mathrm{x}$ stem thickness) 0.28 (in vitro dry matter digestibility $\mathrm{x}$ stem thickness), $\mathrm{r} 2=0.31, \mathrm{P}=0.0044$. It was concluded that horses showed preference to alfalfa hay, wherein the best type A bales. Therefore to predict of preference of the equines for high quality alfalfa hay it's necessary to select bales with lower values of stem thickness and fiber in acid detergent, as well as presenting high level of dry matter digestibility.

Keywords: conserved forages, horses, Medicago sativa, palatability

\section{RESUMO}

O objetivo com este estudo foi identificar preditores de preferência pelo feno de alfafa pelos cavalos. Foram utilizados 15 cavalos da raça quarto de milha, com idade média e peso corporal de 10 anos e $500 \mathrm{~kg}$, respectivamente. Foi realizada uma avaliação para identificar a preferência pelo feno de alfafa por cavalos em testes de curto período de $10 \mathrm{~min}$. Esta avaliação foi realizada em pares para cada teste de feno (1-30) em relação a cada padrão (A, B, C), até a conclusão de todas as combinações resultantes. As variáveis avaliadas foram constituídas por análises etológicas, morfológicas, microbiológicas, bromatológicas e biológicas. Os cavalos mostraram preferência pelo tipo A de feno de alfafa, seguido do tipo B e C. A preferência pelo tipo A do feno de alfafa pode ser predita pela equação: Pref. $A=-98,19$ $+1,61(\mathrm{ADF})+1,53(\mathrm{IVDMD})+18,54(\mathrm{ST})-$ 0,03 (ADFxIVDMD) - 0,02 (ADFxST) - 0,28 (IVDMDxST), $\mathrm{r} 2=0,31, \mathrm{P}=0,0044$. Concluiuse que os cavalos mostraram preferência ao feno de alfafa, em que os melhores fardos do tipo A podem ser identificados selecionando-os porque eles contêm baixas quantidades de espessura do caule e fibra de detergente ácido, bem como altos níveis de digestibilidade da matéria seca in vitro.

Palavras-chave: forragem conservada, cavalos, Medicago sativa, palatabilidade 


\section{INTRODUCTION}

The equines are herbivores animals that to consuming great amounts of forage containing high level of fiber, with special ability in selecting them (DULPHY et al., 1997). However, considering that most part of the horse owners set a limited area for pasture, and that there's seasonality of the production of forage, it becomes important to give a good quality of hay to this animal species. Equine athlete need from 1.6 to 2.3 tons of hay a year, representing about $20 \%$ of the total cost in the maintenance of this animal (GIBBS, 2005).

The alfalfa hay is one of the main legume species commercialized for this animal species characterized for presenting energy concentration, from medium to low, and variable levels of protein and fiber (FISHER et al., 2002). The lack of standardization of the available hay on the market makes it difficult for the owners to ensure the purchase of bales with a good nutritional composition, which could reduce the cost of purchase of concentrated feed in about 15\% (DOMINGUES, 2009).

Therefore, it's necessary to have more objective measures developed in order to assess the quality of the alfalfa hay once it should be commercialize according to its nutritional value, considering the horse preference. The knowing of the characteristics of the alfalfa hay which make the equines prefer it and the development of a reliable and fast method which could predict this understanding could be an important accurate assessment tool for the biological modifications manifested by the equines. It is worth noting that there is no scientific literature on this subject in the literature consulted for horses, and there are only publications in the experimentation with the bovine species
(FLINN et al., 2005). To that extent, the objective of this study was to identify the predictors of preference founded on the ethological (chewing motion), morphological (color, leaf:stem ratio and stem thickness), microbiological (fungi counting), bromatological (neutral detergent fiber, acid detergente fiber, crude protein and water-soluble carbohydrates) and biological characteristics (in vitro dry matter digestibility) of this forage area.

\section{MATERIAL AND METHODS}

This research was carried out at Haras RR, located in the city of São Pedro - SP. This study was certified by the Ethical Comity for Animal Use (ECAU), of the Animal Husbandry Course, São Paulo State University (UNESP), Dracena Campus, Brazil, under number 17/2012, according to the ethical principle of animal experimentation. Fifteen quarter horses at average age of 10 years and average body weight of $500 \mathrm{~kg}$ were used. The horses were hosted in individual stalls during the test period (period in which the tests of preference for horses), and the access to the paddocks in groups of three animals was allowed in the times of rest (period in which the horses were not undergoing trial evaluation). The water was ad libitum available both in the stalls and the paddocks.

The nutritional analysis (protein and fiber) of the available alfalfa hay on the market was made in the pre-experimental period. Thus three categories were formed (A, B, C) according to those data. Alfalfa hays classified as $\mathrm{A}, \mathrm{B}$ and $\mathrm{C}$, contained on average $22.88,17.78$ and $13.16 \%$ of crude protein $(\mathrm{CP})$, respectively. After that, 30 types of bales of alfalfa hay were selected to obtain different nutritional composition, representative from the ones 
initially analyzed. These were the bales chosen for the tests. Thirty types of bales of different alfalfa hay, which are available for purchase in the market, covering the greatest possible variability in protein terms, were collected. Thus, the ten first test-bales (1-10) came from alfalfa hay of high category (24.08 $21.00 \% \mathrm{CP}$ ), the 11 to 20 test-bales of a medium category $(20.99-17.00 \% \mathrm{CP})$ and the 21 to 30 ones from an inferior category $(16.99-12.66 \% \mathrm{CP})$. Then, is expected to find differences in the preference responses among the testalfalfa hays ( 1 to 30 , containing $24.08-$ $12,66 \% \mathrm{CP}$, respectively) and the standard ones (A, B, C, containing 22.88, 17.78 and $13.16 \% \quad \mathrm{CP}$, respectively), offered to the equines.

The term preference, used in this study, represents a behavior particularity shown by a horse when it was allowed him to choose something instead of another one. Therefore the measure of preference shown by the test-hay is expressed, in the form of log-relation, determined by the natural logarithm (NL) of the relation between the hay tests and the standard ones (FLINN et al., 2005), as following: Preference $=$ NL $x$ (total of consumed hay test, $\mathrm{kg}$ / total of consumed hay standard hay, $\mathrm{kg}$ ).

The logarithmic transformation allows a more informative measure of preference than the not transformed value. So, the preference measure, whose value is equal zero, represents preference for the standard hay; positive number indicates that the animals prefer the hay test and negative number shows higher preference to the standard hay.

First, an annotation was made of the horses' ingestion, at each every 10 minutes (short-period) according to Shingu et al. (2001). This evaluation was made, in pairs, for each experimental hay (1 to 30 ) versus each standard one (A, B, $\mathrm{C})$, up to the finalization of all resultant combinations, through three horses and replicated three times/animal. This way, the tests were divided into sessions, in the morning (MP) and afternoon (AP) periods, allowing the ethological evaluation through the counting of chewing motions (movements/minute) and the medium value of preference of the combination of the test hays and standard ones, during the experimental period of six months, with the duration of two months of evaluation of each standard hay compared to test hays.

The horses daily laid on the paddocks in the evening period and in the morning they were taken to their stalls. All the animals fasted for one hour before each test session (MP and AP) according Kenney \& Black (1984). In the beginning of each session, bags containing hay test were put in the left side of the stalls. The measurement of the value of preference consisted of giving the horses $1 \mathrm{~kg}$ of test hay and $1 \mathrm{~kg}$ of one of the standard hays (A, B, C), simultaneously in two adjacent bags, for ten minutes. After this period the hay that had not been consumed was removed and weighed to set, relatively, the consumed amount by each one. This sequence was repeated until three replications were completed by each horse. It should be highlighted that the position of the bag in each replication was changed (right versus left), according to recommendations of the authors Kenney \& Black (1984).

Samples of all test and standard alfalfa hays of each period of evaluation were taken and stored in sealed plastic sacks for posterior morphological, microbiological, bromatological and biological determination analysis. On Table 1 shows the groups of analysis, containing the description of the explanatory variables assessed in this study, to predict the preference for alfalfa hay by equines. 
Table 1. Groups of analysis, description of the explanatory variables, unit and abbreviation to predict the preference for alfalfa hay by horses

\begin{tabular}{llcc}
\hline Groups of analysis & Description of the explanatory variables & Unit & Abbreviation \\
\hline Ethological & Chewing motion & Mov/min & CM \\
\hline \multirow{3}{*}{ Morphological } & Color & Score $(1-5)$ & COR \\
& Leaf:Stem ratio & - & LSR \\
& Stem thickness & $\mathrm{mm}$ & $\mathrm{ST}$ \\
\hline Microbiological & Fungi counting & $\log (\mathrm{CFU})$ & $\mathrm{FC}$ \\
\hline \multirow{4}{*}{ Bromatological } & Neutral detergent fiber & $\%$ in DM & NDF \\
& Acid detergente fiber & $\%$ in DM & ADF \\
& Crude protein & $\%$ in DM & CP \\
& Water-soluble carbohydrates & $\%$ in DM & WSC \\
\hline Biological & In vitro dry matter digestibility & $\%$ & IVDMD \\
\hline
\end{tabular}

The analysis of the morphological characteristics of hays were made by measuring color (COR), leaf: stem ratio (LSR) and stem thickness (ST), which were carried out in the Vegetal Morphology and Physiology Laboratory at UNESP, Experimental Campus in Dracena. The degree of coloration of the hay was determined by the direct comparison of each sample of hay at a graduated scale of color, varying from 1 (color associated to brown hay) to 5 (representing dark green hay), according to Kugler (2004). The leaf-stem ratio was determined as the proportion of leaves and stems in a plant, obtained through a mathematical calculation, from the weighing of leaves, divided by the weight of the stem (RADUNZ, 2005). The stem thickness was determined by measuring 10 stems at random in the chosen sample, using a caliper of about 1 mm (GOMES, 2004).

The microbiological analysis were carried out in the Microbiology Laboratory at UNESP - Experimental Campus in Dracena - from the preparation of the samples by adding $450 \mathrm{~mL}$ of autoclaved ringer solution $\left(121^{\circ} \mathrm{C}\right.$ for $\left.15 \mathrm{~min}\right)$ to $50 \mathrm{~g}$ of sample. These substrates were incubated in extract plates of Sabouraud agar at $30^{\circ} \mathrm{C}$, and grew up for 144 hours for the fungi counting (SEALE et al., 1986).

The bromatological composition of the alfalfa hay was made by the analysis of dry matter (DM), neutral detergent fiber (NDF), acid detergent fiber (ADF), crude protein (CP) and water-soluble carbohydrates (WSC), set at the Bromatology Laboratory, at the Faculty of Veterinary Medicine and Animal Science at UNESP - Campus Botucatu. The content of DM e CP were set by a method described by AOAC (1990), while the NDF and ADF was according to Van Soest et al. (1991) and WSC determined according to Larsson \& Bengtsson (1983).

The biological analysis was evaluated by the dry matter digestibility through the use of the in vitro technique. This technique was carried out by using the equipment Daisy Incubator (ANKOM ${ }^{\circledR}$ Technology), and an adapted methodology developed by Oliveira et al. (2012). For this purpose, equine stool samples were collected from a castrated horse weighing $400 \mathrm{~kg}$, which had been consuming alfalfa hay. The samples were collected from the rectum of the animal, before the first meal of the day, and packed in a thermal bag and taken to the laboratory. In this place, the samples of stool were mixed with artificial saliva, heated at $39^{\circ} \mathrm{C}$ (McDOUGALL, 1948) in 
a blender, in the proportion of $1: 1$, based on the in natura weight and let it bubble with CO2 (El SHAER et al., 1987), which originated the faecal mixture. This mixture was filtered in layers of sterile gauzes and diluted in artificial saliva again to obtain a faecal solution at 3\%. Urea solution at 3\% was added to this solution, in the proportion of 3:100 (urea solution: faecal solution), which resulted in the diluted faecal solution, in which $\mathrm{CO} 2$ was injected again for five minutes. Therefore this diluted faecal solution was obtained by adding $30 \mathrm{~mL}$ of faecal mixture, $1.000 \mathrm{~mL}$ of artificial saliva and $30 \mathrm{~mL}$ of urea solution at $3 \%$ in a $2 \mathrm{~L}$ becker. After these procedures, $400 \mathrm{~mL}$ of diluted faecal solution plus $1.600 \mathrm{~mL}$ of artificial saliva were added to the jars containing 25 filter bags (model F57 Filter Bags), each with $0.5 \mathrm{~g}$ of the sample, bubbling with $\mathrm{CO} 2$, packed and taken to incubation for 144 hours.

After the evaluation of all analysis groups (ethological, morphological, microbiological, bromatological and biological), it was possible to characterize all test and standard alfalfa hay used in this study, which medium, minimum and maximum values are described in Table 2.

Table 2. Averages values of analyzed variables for alfalfa hays offered to horses for each standard hay (A, B and C) and maximum (Max.), minimum (Min.) and average results relating to hay tests

\begin{tabular}{|c|c|c|c|c|c|c|}
\hline \multirow{2}{*}{ Variable } & \multicolumn{3}{|c|}{ Standard alfalfa hay } & \multicolumn{3}{|c|}{ Alfalfa hay test } \\
\hline & $\mathrm{A}$ & $\mathrm{B}$ & $\mathrm{C}$ & Max. & Min. & Average \\
\hline \multicolumn{7}{|c|}{ Ethological analysis } \\
\hline $\mathrm{CM}^{1}(\mathrm{mov} / \mathrm{min})$ & 69.50 & 60.00 & 49.93 & 74.63 & 57.44 & 66.88 \\
\hline \multicolumn{7}{|c|}{ Morphological analysis } \\
\hline $\mathrm{COR}^{2}$ (escore $\left.1-5\right)$ & 4.85 & 3.95 & 3.80 & 5.00 & 3.50 & 4.20 \\
\hline $\mathrm{LSR}^{3}$ & 0.77 & 0.71 & 0.46 & 1.47 & 0.32 & 0.73 \\
\hline $\mathrm{ST}^{4}(\mathrm{~mm})$ & 1.70 & 1.60 & 1.85 & 2.00 & 1.30 & 1.63 \\
\hline \multicolumn{7}{|c|}{ Microbiological analysis } \\
\hline $\mathrm{FC}^{5}(\log$ de CFU $)$ & 1.19 & 3.88 & 4.62 & 4.62 & 0.00 & 2.87 \\
\hline \multicolumn{7}{|c|}{ Bromatological analysis } \\
\hline $\mathrm{NDF}^{6}(\% \mathrm{DM})$ & 53.26 & 58.96 & 60.00 & 77.36 & 53.36 & 61.55 \\
\hline $\mathrm{ADF}^{7}(\% \mathrm{DM})$ & 28.34 & 38.21 & 39.31 & 53.60 & 24.02 & 37.27 \\
\hline $\mathrm{CP}^{8}(\% \mathrm{DM})$ & 22.88 & 17.78 & 13.16 & 24.08 & 12.66 & 18.37 \\
\hline $\mathrm{WSC}^{9}(\% \mathrm{DM})$ & 17.69 & 9.21 & 7.24 & 19.63 & 4.47 & 11.91 \\
\hline \multicolumn{7}{|c|}{ Biological analysis } \\
\hline $\operatorname{IVDMD}^{10}(\%)$ & 69.10 & 54.22 & 51.14 & 68.65 & 48.82 & 59.94 \\
\hline
\end{tabular}

The equations to predict the preference for hay by the horses were developed using independent variants collected for each type of hay, including the value of the preference log, chewing motions (CM), morphological characteristics
(COR, LSR, ST), fungi counting (FC), bromatological characteristics $(\mathrm{NDF}$, $\mathrm{ADF}, \mathrm{CP}, \mathrm{WSC}$ ) and IVDMD. Before the development of the prediction equations, the analysis of the correlation of the Pearson coefficients of the explanatory 
variants was made, to enhance the coefficient of determination (R2) of the prediction models. This analysis permitted the investigation of the presence of an important effect of the variable in its group of analysis about the prediction of preference by horses. Thus the non-significant variables were removed from the prediction model, and the equations of preference were structured, enabling the inclusion of all the variables and their products for each group of analysis, to examine the possible combinations and check which equation would better represent the model of prediction. When only one dependent variable was included in the model, the data were analyzed through simple linear regression. When two dependent variables were included in the model, the multiple regression analysis was used.

All the results of the analysis of the variables performed in this study were submitted to the program Statistical Analysis System (SAS, 2000). The correlation of the coefficients of Pearson was analyzed through COR procedure. The equations of prediction were submitted to analysis through REG and GLM, for simple and multiple regressions, respectively. Also, the comparisons between the averages of preference for alfalfa hay were made using the Tukey test, at the level of 5\% of significance.

\section{RESULTS AND DISCUSSION}

The values of the logarithm of the relation between the test and standard hay consumed are in Table 3. Difference was noticed $(\mathrm{P}<0.05)$ for the preference for alfalfa hays-test to the standard hays $\mathrm{A}, \mathrm{B}$ and $\mathrm{C}$, in which the average values were $-2.0439,-1.5481$ e 1.0584, respectively. This result indicates the alfalfa hay type A was preferred by the equines, while the standard hay $\mathrm{C}$ was rejected during the short periods of preference while compared to the alfalfa hay-tests.

Table 3. Standard alfalfa hay (A, B and C) preference values (Pref) offered to the horses, and min (Min), maximum (Max.) and Average value with standard deviation (SD), relative to hay-test offered to each standard hay

\begin{tabular}{llllllll}
\hline \multirow{2}{*}{ Item } & \multicolumn{3}{c}{ Alfalfa hay - Standard } & \multicolumn{4}{c}{ Alfalfa hay - Test } \\
\cline { 2 - 8 } & $\mathrm{A}$ & $\mathrm{B}$ & $\mathrm{C}$ & Min. & Max. & Average & $\mathrm{SD} \pm$ \\
\hline PrefA $^{1}$ & 0.0000 & 0.4957 & 3.1023 & -5.2418 & 3.5264 & $-2.0439^{\mathrm{a}}$ & 1.8839 \\
PrefB $^{2}$ & -0.4957 & 0.0000 & 2.6065 & -12.2111 & 2.0477 & $-1.5481^{\mathrm{b}}$ & 2.1364 \\
PrefC $^{3}$ & -3.1023 & -2.6065 & 0.0000 & -4.3438 & 4.8904 & $1.0584^{\mathrm{c}}$ & 2.3963 \\
PrefAverage $^{4}$ & -1.1993 & -0.7036 & 1.9029 & -12.2111 & 4.8904 & -0.8297 & 2.5454 \\
\hline
\end{tabular}

${ }^{1}$ Preference by equine when offered in combination to standard hay A (ratio log); ${ }^{2}$ Preference by equine when offered in combination to standard hay B (ratio log); ${ }^{3}$ Preference by equine when offered in combination to standard hay $\mathrm{C}$ (ratio $\log$ ); ${ }^{4}$ Average preference among $\mathrm{A}, \mathrm{B}$ and $\mathrm{C}$ standard hays (ratio $\log ) ;{ }^{\text {a,b,c }}$ Averages with different letters in the same column differ $(\mathrm{P}<0.05)$ among itself by Tukey test.

Flinn et al. (2005) and Pain \& Revell (2009) verified the same response behavior in the present research, in which the alfalfa hay A was preferred by the horses to the $\mathrm{B}$ and $\mathrm{C}$ types. These researchers based the low preference by equines to alfalfa hay regular type on the worst nutritional quality (PAIN \& 
REVELL, 2009), which was an expected response. However, this result proves that the equines have the ability of presenting preference for the alfalfa hay available for sale. This fact shows the inclusion of preference as a parameter in the assessment and classification of the alfalfa hay targeted to the nutrition of this animal species. Also, few studies related to the viability of the variables as predictors of preference for the alfalfa hay restricts the discussion of the possible results.

The coefficient of equation to predict the preference of equines for alfalfa hay, originated from the ethological variable are on Table 4. An important effect was noticed $(\mathrm{P}<0.01)$ in the chewing motion related to the preference for alfalfa hay by equines, in which this variable was responsible for $15.3 \%$ of the variation in preference for alfalfa hay type A. This response shows that the horses selected the alfalfa hay, based on the ease at executing chewing to reduce the size of the particle. This situation resulted values for high chewing motions to the alfalfa hay type A, for this type contains less content of fiber what increases the speedy of chewing when compared to types B and C (Table 2).

Table 4. Coefficient of equation to predict the preference for alfalfa hay by horses, originated from the chewing motions $(\mathrm{CM})$, with relative values to equation (constant, variable coefficient and R2) for A (Pref.A), B (Pref.B), C (Pref.C) and average preference (Average Pref.) to standard hays

\begin{tabular}{lccc}
\hline \multirow{2}{*}{ Item } & \multicolumn{3}{c}{ Coefficient } \\
\cline { 2 - 3 } & Constant & $\mathrm{CM}$ & $\mathrm{R}^{2}$ \\
\hline Pref.A & -12.81 & 0.16 & 0.153 \\
s.e.* & 1.93 & 0.03 & \\
P-value & 0.0001 & 0.0001 & \\
Pref.B & -5.58 & 0.06 & 0.016 \\
s.e. & 2.36 & 0.04 & \\
P-value & 0.0193 & 0.0934 & 0.003 \\
Pref.C & -0.86 & 0.03 & \\
s.e. & 2.52 & 0.04 & \\
P-value & 0.7333 & 0.4461 & 0.024 \\
Average Pref. & -6.41 & 0.08 & \\
s.e. & 1.55 & 0.02 & \\
P-value & 0.0001 & 0.0001 & \\
\hline
\end{tabular}

*s.e. $=$ standard error.

The chewing motions reflects the efficiency of the reduction of the particle size ingested by the horse (BONIN et al., 2007), and the easier it is to chew food, more chewing motions the horse will make because less effort it will take him for that. Thus the values for CM, observed in the present study, express less resistance in the decrease of the particle of the ingested material, allowing higher speedy in the chewing process. According to Vincent (1990), the higher slowness in chewing during bulky food consumption comparing to concentrated ingredients is based in the fiber content of the food and probably by the open physical structure of this fiber. Also, Zanine et al. (2006) reported that grazing equines choose the forage which represents less chewing effort for it increases the DM ingestion, which is a relevant characteristic of animal of 
this type of farming.

The coefficients of prediction equation of alfalfa hay, originated from the morphological characteristics, are in Table 5. A relevant effect of this equation $(\mathrm{P}=0.3744)$ was not noticed to predict the preference for alfalfa hay by equines. However, the characteristics of alfalfa hay, coloration $(\mathrm{P}=0.0011)$ and the thickness of the stem $(\mathrm{P}=0.0097)$, were relevant to determine the preference of the horses. The highest values of preference by equines occurred to hay with more intense green coloration, that is positively correlated
(0.6472), while the thickness for the stem presented a negative correlation (1.4534). Similarly, Pain \& Revell (2009), investigating the preference for alfalfa and oat hay, verified that the diameter of the stem and the interaction among the variables, coloration and diameter of the stem for oat hay, and the coloration of alfalfa hay were important in the preference by the animals. Also, these researchers found a negative correlation of the diameter of the stem over the alfalfa hay by equines, according to the results of the present study.

Table 5. Coefficient of equation to predict the preference for alfalfa hay by horses, originated from the morphological characteristics of coloration (COR) and average stem thickness (ST), with relative values to equation (constant, variable coefficient and R2) for average preference (Average Pref.) of standard hays

\begin{tabular}{lcccc}
\hline \multirow{2}{*}{ Item } & \multicolumn{4}{c}{ Coefficient } \\
\cline { 2 - 5 } & Constant & COR & $\mathrm{ST}$ & $\mathrm{R}^{2}$ \\
\hline Average Pref. & -1.1628 & 0.6472 & -1.4534 & \\
s.e. ${ }^{*}$ & 1.30818 & 0.1980 & 0.5598 & 0.0353 \\
P-value & 0.3744 & 0.0011 & 0.0097 & \\
\hline
\end{tabular}

*standard error.

Most of the owners and trainers prefer to buy hay with a dark green coloration, one of the most important characteristics for sale of the hay designed to equines nutrition (KUGLER, 2004). Contradictorily, Cannas et al. (2010) reported that the horses can't distinguish yellow and green in the forage area, differently to what occurs with humans, which is not an important characteristic of the equines. However a significant effect of the coloration was noticed in the present study related to the preference of the equines for alfalfa hay. That result occurred due to the high correlation among the variables, coloration and thickness of the stem. It provided the occurrence of this ambiguity, in which two affirmatives are correct, because the choice of alfalfa hay with a thinner stem from young plants resulted, simultaneously, in greener hay.

The equation of fungi counting (FC), as a predictor of preference for alfalfa hay by equines is in Table 6 . The fungi count presented a significant effect $(\mathrm{P}=0.0225)$ to predict the preference for alfalfa hay by equines, in which $8 \%$ of the answer variation can be explained by this variable. Yet, the elevation of the fungi count in the alfalfa hay was inversely correlated $(-0.12)$ with the values of preference by equines. 
Table 6. Coefficient of equation to predict the preference for alfalfa hay by horses, originated from the fungi counting (FC), with relative values to equation (constant, variable coefficient and R2) for A (Pref.A), B (Pref.B), C (Pref.C) and average preference (Average Pref.) to standard hays

\begin{tabular}{lccc}
\hline Item & \multicolumn{3}{c}{ Coefficient } \\
\cline { 2 - 4 } & Constant & FC & $\mathrm{R}^{2}$ \\
\hline Pref.A & -1.92 & 0.00 & 0.000 \\
s.e.* & 0.27 & 0.08 & \\
P-value & 0.0001 & 0.9983 & \\
Pref.B & -1.20 & -0.14 & 0.013 \\
s.e. & 0.31 & 0.09 & \\
P-value & 0.0001 & 0.1210 & 0.032 \\
Pref.C & 1.72 & -0.23 & \\
s.e. & 0.32 & 0.09 & 0.008 \\
P-value & 0.0001 & 0.0167 & \\
Average Pref. & -0.47 & -0.12 & \\
s.e. & 0.20 & 0.06 & \\
P-value & 0.0225 & 0.0394 & \\
\hline
\end{tabular}

*s.e. $=$ standard error.

The presence of fungi in the hay is negatively related to its quality, which makes it difficult to be commercialized, because the horses reject this type of food. Additionally, Horne et al. (1991) observed that, independently of the nutritive value of the forage, the presence of fungi leads to animal rejection. Similarly, in the present study, the fungi count was decisive to explain the variation in the preference for alfalfa hay by horses. The average value (4.62 $\log$ of UFC) observed in the alfalfa hay type $\mathrm{C}$ (Table 2), was enough to reflect in lower values for preference $(\mathrm{P}=0.0167)$ for alfalfa hay by the horses. Additionally, Kugler (2004) reported that the horses are affected by the presence of fungi in the food when there are secondary metabolites produced by Aspergillis sp. Calviceps, Fusarium sp. and Penicillium sp., though the identification of fungi was not the subject of this experiment.

The model of prediction for preference for alfalfa hay by equines based on the bromatological characteristic is in Table
7. The model was significant $(\mathrm{P}=0.013)$ to predict the preference for alfalfa hay by horses in which ADF was responsible for $20.37 \%$ of the variation in choice of alfalfa hay type $\mathrm{C}$ by equines. This result was inferior to the one found by Pain \& Revel (2009), whose average value was $47 \%$, obtained for equation of prediction containing the variables $\mathrm{ADF}$ and hemicellulose to alfalfa hay type $\mathrm{C}$ for the same animal species. The best answer of the variable ADF to the variation in the preference for alfafa hay (current essay) and alfalfa hay type $\mathrm{C}$ (essay above) was probably possible due to the presence of high content of this nutrient, in the bales of lower category (Table 2). This shows that the ADF can become an important predictor of preference for alfalfa hay by the equines. Also, in the present study the level of ADF present in the alfalfa hay correlated negatively (0.0599) with the preference by the horses, similarly to the one found by Pain \& Revel (2009). 
Table 7. Coefficient of equation to predict the preference for alfalfa hay by horses, represented by acid detergent fiber (ADF), with relative values to equation (constant, variable coefficient and R2) for A (Pref.A), B (Pref.B), C (Pref.C) and average preference (Average Pref.) to standard hays

\begin{tabular}{lccc}
\hline \multirow{2}{*}{ Item } & \multicolumn{3}{c}{ Coefficient } \\
\cline { 2 - 3 } & Constant & ADF & $\mathrm{R}^{2}$ \\
\hline Pref.A & -4.109 & 0.0589 & 0.0473 \\
s.e. ${ }^{*}$ & 0.7522 & 0.0198 & \\
P-value & 0.0001 & 0.0034 & \\
Pref.B & 1.7623 & -0.0904 & 0.0858 \\
s.e. & 0.8396 & 0.0221 & \\
P-value & 0.0373 & 0.0001 & 0.2037 \\
Pref.C & 6.5512 & -0.1474 & \\
S.e. & 0.8295 & 0.0218 & \\
P-value & 0.0001 & 0.0001 & 0.0288 \\
Average Pref. & 1.4178 & -0.0599 & \\
s.e. & 0.5690 & 0.0149 & \\
P-value & 0.0130 & $<0.0001$ & \\
\hline
\end{tabular}

*.e. $=$ standard error.

The alfalfa hay is one of the most important foods used by equines, due to its nutritional value. However, its nutritional value can be drastically reduced due to time of harvesting for haymaking. It is known that with the advance in age of the plant an increase in the deposition of the cell wall, with a reduction in the proteic and hemicellulose level. The lignin is one of the most important nutrients which most suffers changes with the ageing of the forage (ZANINE et al., 2006). Those observations justify the best response of the $\mathrm{ADF}$, among the nutritional variables evaluated, in the present study, to compose the prediction model of preference for alfalfa hay by the horses. The same presumption, mentioned before, was responsible for the exclusion of the variable $\mathrm{CP}$ as a predictor of preference for alfalfa hay by equines, because according to the data presented in Table 2, the proteic content was reduced in the bales type $\mathrm{A}$ to $\mathrm{C}$. Therefore, the equines were sensible only to the addition in the ADF content in the alfalfa hay, during its process of choosing, with preference to bales containing lower participation of this variable and, consequently, making it promising to compose the prediction model for alfalfa hay for this animal species.

The equations to predict the preference for alfalfa hay by equines from the in vitro of the dry matter digestibility are in Table 8 . The use of IVDMD to predict the values of preference for hay lucerne turned out to be significant $(\mathrm{P}=0.0001)$ and positively correlated $(0.08)$, in other words, the horses preferred the hay with best digestibility of DM. In the present study, the IVDMD was responsible for $19.5 \%$ of the variation in the preference for alfalfa hay type $\mathrm{C}$, which is inferior to the results found by Pain \& Revel (2009), who worked with horses eating alfalfa hay, in which the variable IVDMD was responsible for $40 \%$ of the variation in the preference.

The average value of IVDMD to alfalfa hay was $59.94 \%$ (Table 2), similar to the one found in the literature of $58.4 \%$ for the same forage (FLINN et al., 2005; EDOUARD et al., 2008). It can be inferred by this observation that the methodology in vitro, in the present study, determined satisfactorily the digestibility of the dry matter for equines. 
Table 8. Coefficient of equation to predict the preference for alfalfa hay by horses, in relation to in vitro dry matter digestibility (IVDMD) of hay, with relative values to equation (constant, variable coefficient and R2) for A (Pref.A), B (Pref.B), C (Pref.C) and average preference (Average Pref.) to standard hays

\begin{tabular}{lccc}
\hline \multirow{2}{*}{ Item } & \multicolumn{3}{c}{ Coefficient } \\
\cline { 2 - 3 } & Constant & IVDMD & $\mathrm{R}^{2}$ \\
\hline Pref.A & 2.49 & -0.07 & 0.037 \\
s.e.* & 1.68 & 0.03 & \\
P-value & 0.1399 & 0.0092 & \\
Pref.B & -8.15 & 0.11 & 0.064 \\
s.e. & 1.89 & 0.03 & \\
P-value & 0.0001 & 0.0006 & 0.195 \\
Pref.C & -11.08 & 0.20 & \\
s.e. & 1.85 & 0.03 & \\
P-value & 0.0001 & 0.0001 & 0.026 \\
Average Pref. & -5.58 & 0.08 & \\
s.e. & 1.27 & 0.02 & \\
P-value & 0.0001 & 0.0002 & \\
\hline
\end{tabular}

*.e. $=$ standard error.

The literature has indicated the IVDMD as the best predictor of preference for leguminous hay Pain \& Revel (2009). This recommendation is not surprising because of the association of this variable with the structure components of the plant, which impacts directly in its morphological and chemical parameter, as the thickness of the stem and ADF, respectively (Table 2). Besides, these variables presented significant effects over the preference for alfalfa hay by equines. Also, the great variability of the assessed characteristics among the alfalfa hay type A, B and C, selected for this research, allowed to express the responses of preference by equines in a better way, which enabled the use of the IVDMD in a prediction model.

The preference depends on chemical, morphological and microbiological factors, present on the alfalfa and especially, there's a great interference of the biological factor, it is to say, the horse. It's apparent among the equine species the presence of individual characteristics which directly affect the responses of the scientific studies. According to Edouard et al. (2008), it's usual to observe the individuality in the experiments with horses which highly interferes in the results. Probably the low coefficients of determination to the prediction models evaluated, happened due to the individuality of the animals. However, these data allowed the identification of important variables in the choosing process, it is to say, in the preference for alfalfa hay by equines such as chewing movement, coloration, stem thickness, fungi counting, acid detergent fiber and digestibility of dry material.

Among the significant variables to preference by horses, listed above, ADF, IVDMD and ST were outlined to compose a multivariate model, aiming to increase the $\mathrm{R} 2$ of the prediction equation of the present study. This way, the preference for alfalfa hay type A (Pref. A) by equines, was predicted by the equation:

Pref. $\mathrm{A}=-98.19+1.61(\mathrm{ADF})+1.53(\mathrm{IVDMD})+18.54(\mathrm{ST})-0.03(\mathrm{ADFxIVDMD})-$ $0.02(\mathrm{ADFxST})-0.28(\mathrm{IVDMD} x \mathrm{ST}), \mathrm{R} 2=0.31, \mathrm{P}=0.0044$. 
Thus, if this equation results in a positive value, it means that horses do not prefer this type of hay and therefore, if this result is negative, it shows that the alfalfa hay is preferred by horses.

However, when it's not possible to obtain good alfalfa hay, as in the period of dry season and intercrop, the identification of bales with best values of preference should be done by using the following prediction equation: Pref. $=6.55-$ 0.15(ADF), R2 $=0.20, \quad \mathrm{P}<0.0001$. The application of this prediction equation for the inferior alfalfa hays will reduce the rejection rate of this food, once that the alfalfa hay type $\mathrm{C}$ were rejected by the horses (Table 4).

It is worth noting that the inclusion of the preference in the determination of the quality of the hay may add value to them when commercialized by the hay producers. Also the release of hay selected by preference on the market may offer options of forage to the farmers that promote consumption by horses. This is a relevant fact because the horses should be stimulated to eat their food in some periods of their lives, such as at ageing and convalesce time, especially the equines which participate in high performance equestrian activities.

To predict of preference of the equines for high quality alfalfa hay it's necessary to select bales with lower values of stem thickness and fiber in acid detergent, as well as presenting high level of dry matter digestibility.

\section{ACKNOWLEDGMENT}

This research was funded by the Sao Paulo Research Foundation (FAPESP), under research assistance $n^{\circ}$ 12/13656-9. The development of this research was conducted at Haras RR in Sao Pedro / SP, and with help of employees of the stud farm and teachers and students of São Paulo State University (UNESP), Campus de Dracena/ SP.

\section{REFERENCES}

ASSOCIATION OF OFFICIAL AGRICULTURAL CHEMIST - AOAC. Official methods of analysis. 14th ed. Washington, DC, 1990. 1422p.

BONIN, S.J.; CLAYTON, H.M.; LANOVAZ, J.L.; JOHNSTON T. Comparison of mandibular motion in horses chewing hay and pellets. Equine Veterinary Journal, v.39, p.258-262, 2007.

CANNAS, A.; MEREU, A.; DECANDIA, M.; MOLLE, G. Role of sensorial perceptions in feed selection and intake by domestic herbivores.

Italian Journal of Animal Science, v.8, p.243-252, 2010.

DOMINGUES, J.L. Use of Preserved Bulky Food in Equine Nutrition. Brazilian Journal of Animal Science, v.38, p.259-269, 2009.

DULPHY, J.P.; MARTIN-ROSSET, W.; DUBROEUCQ, H.; JAILLER, M. Evaluation of voluntary intake of forage trough-fed to light. Comparison with sheep. Factors of variation and prediction. Livestock Production

Science, v.52, p.97-104, 1997.

EDOUARD, N.; FLEURANCE, G.; MARTIN-ROSSET, W.; DUNCAN, P.; DULPHY, J.P., GRANGE, S.; BAUMONT, R.; DUBROEUCQ, H.; PÉREZ-BARBERÍA, F.J.; GORDON, I.J. Voluntary intake and digestibility in horses: effect of forage with enphasis on individual variability. Animal

Consortium, v.2, n.10, p.1526-1533, 2008. 
El SHAER, H.M.; OMED, H.M.; CHAMBERLAIN, A.G. Use of faecal organisms from sheep for the "in vitro" determination of digestibility. Journal of Agriculture Science, v.109, p.257259, 1987.

FISHER, D.S.; MAYLAND, H.F.; BURNS J.C. Variation in ruminant's preference for tall alfalfa hays cut a sunup and sundown. Crop Science, n. 42, p.231-237, 2002.

FLINN, P.; KNOTT, S.; CUMMINS, L.; DALLEY, D. Objective Measurement of Fodder Quality Across Animal Species, RIRDC Publication No 05/088, RIRDC Project No DAV 187A. Australia: Rural Industries Research and Development Corporation, 2005.

GIBBS, P.G. Selection and use of hay and processed roughage in horse feeding. Department of Animal Science. Texas, EUA: Texas A\&M University, 2005. p. 63.

GOMES, C.S. Ryegrass and White Oat as Factors of Influence on the Ingestive Behavior of the Equines. 2004. 38p. Thesis (Master in Agronomy) - Universiddae Federal do PAraná, Curitiba. Available in:

http://acervodigital.ufpr.br/handle/1884/ 28836.

HORNE, C.W.; BOLEMAN, L.L.; COFFMAN, C,G.; DENTON, J.H.; LAWHORN D.B.; THOMAS, W.B.; WAGNER, J.R.; WALLER, M.L.; VALCO, T.D.; WOELFEL, C.G. Mycotoxins in feed and foodproducing crops. Texas Agricultural Extension Service. Texas, EUA: Texas A\&M University System, College Station, Texas, 1991.
KENNEY, P.A.; BLACK, J.L. Factors affecting diet selection by sheep. I Potential intake rate and acceptability of feed. Australian Journal of Agricultural Research, v.35, p.551563, 1984.

KUGLER, J. Producing high quality orchardgrass and timothy hay. In: NATIONAL ALFAFA SYMPOSIUM, 2004, San Diego. Proceedings... SanDiego: California Department of Agronomy and Range Science Extension, 2004.

LARSSON, K.; BENGTSSON, S. Determination of water soluble carbohydrates in plant material. In: Eurobac Conference, 1983, Uppsala, Sweden. Proceedings... Uppsala, Sweden, 1983. p. 385-391.

McDOUGALL, E.I. Studies on ruminant saliva. I. Composition and output of sheep saliva. Biochemistry Journal, v.43, p.99-109, 1948.

OLIVEIRA, K,; BITTAR, C.M.M.; COSTA, C.; OLIVEIRA, V.A.B.; SÁ, J.C. Equine Stools as a Source of Inoculum for Obtaining Indigestible Indicators to Estimate the Digestibility in Equines. Brazilian Journal of Animal Health and Production, v.13, p.410-423, 2012.

PAIN, S.; REVEL, D. Identifying predictors of preference between hays. Barton: Rural Industries Researchand Development Corporation, 2009. 107p.

RADUNZ, E. The structure of grasses of genus Cynodon and the ingestive behavior of the equines. $2005.43 \mathrm{p}$. Thesis (Master in Veterinary Science) Universidade Federal do PAraná, Curitiba. Available in: http://acervodigital.ufpr.br/handle/1884/ 3537. 
SEALE; D.R.; PAHLOW; G.;

SPOELSTRA; S.F. Methods for the microbiological analysis of silage. In: Eurobac Conference, 1986, Uppsala, Sweden. Proceedings of the.

Proceedings... Uppsala, Sweden, 1986. p.147-164.

SHINGU, Y.; KONDO, S.; HATA, H.; OKUBO, M. Digestibility and number of bites and chews on hay at fixed level in Hokkaido native horses and light half-bred horses. Journal Equine

Science, v.12, p.145-147, 2001.

Statistical Analysis System - SAS. SAS user's: guide statistics. Cary: 2000.

$211 \mathrm{p}$.

VAN SOEST, P.J.; ROBERTSON, J.B.; LEWIS, B.A. Methods of dietary fiber, neutral detergent fiber and nonstarch polysaccharides in relation to animal nutrition. Journal of Dairy Science, v.74, p.3583-3597, 1991.

VINCENT, J.F.V. Fracture properties of plants. Advances in Botanical

Research, v.17, p.235-287, 1990.

ZANINE, A.M.; SANTOS, E.M.; FERREIRA, D.J.; CECON, P.R. Equine Grazing Habits in Tropical Pastures of Different Structures. Arquivo de Ciências Veterinárias e Zoologia. UNIPAR, v.9, p.83-89, 2006.

Receipt date: 05/01/2018

Approval date: 22/06/2018 